in vivo $33: 1209-1220$ (2019)

doi:10.21873/invivo.11592

\title{
Finasteride Enhances Stem Cell Signals of Human Dermal Papilla Cells
}

\author{
NAPAPAT RATTANACHITTHAWAT ${ }^{1,2}$, TATCHAKORN PINKHIEN ${ }^{3}$, \\ PRANEET OPANASOPIT ${ }^{1,2}$, TANASAIT NGAWHIRUNPAT ${ }^{1,2}$ and PITHI CHANVORACHOTE CH,4 $^{3,4}$ \\ ${ }^{1}$ Department of Pharmaceutical Technology, Faculty of Pharmacy, Silpakorn \\ University, Sanamchan Palace Campus, Nakhon Pathom, Thailand; \\ ${ }^{2}$ Pharmaceutical Development of Green Innovation Group (PDGIG), Faculty of Pharmacy, \\ Silpakorn University, Sanamchan Palace Campus, Nakhon Pathom, Thailand; \\ ${ }^{3}$ Cell-Based Drug and Health Product Development Research Unit, \\ Faculty of Pharmaceutical Science, Chulalongkorn University, Bangkok, Thailand; \\ ${ }^{4}$ Department of Pharmacology and Physiology, Faculty of Pharmaceutical Science, \\ Chulalongkorn University, Bangkok, Thailand
}

\begin{abstract}
Background/Aim: Finasteride (FN) has been widely used to treat androgenetic alopecia (AGA). This study aimed at exploring the effect of FN on DP stem cell properties. Materials and Methods: Effect of FN on stem cell properties was tested in a DP cell line and 2 human primary DP cells (HDPCs 1 and HDPCs 2$)$. Cell toxicity and growth were analyzed by 3-(4,5-dimethylthiazol-2-yl)-2,5diphenyltetrazolium bromide (MTT) assay. The aggregation behavior was observed by phase-contrast microscopy and a scanning electron microscope (SEM). Effects of FN on cell signaling were determined by western blotting and immunocytochemistry. Results: Treatment of DPCs with FN was able to significantly increase their aggregation behavior and the expression of stem cell transcription factors Nanog and Sox-2, when compared to the non-treated control. FN up-regulated stem cell regulatory proteins through the activation of protein kinase $B(A K T), \beta$-catenin, and integrin- $\beta 1$. Conclusion: FN had an interesting biological effect on stem cell induction. These findings support the use of this drug for hair loss control and the development of regeneration approaches.
\end{abstract}

This article is freely accessible online.

Correspondence to: Pithi Chanvorachote, Ph.D., Department of Pharmacology and Physiology, Faculty of Pharmaceutical Sciences, Chulalongkorn University, Bangkok, Thailand. Tel: +662 2188285, Fax: +662 2188340, e-mail: pithi_chan@yahoo.com; Tanasait Ngawhirunpat, Silpakorn University, Nakhon Pathom, Thailand. E-mail: ngawhirunpat_t@silpakorn.edu

Key Words: Finasteride, stem cells, dermal papilla, Wnt//-catenin, Protein kinase B, hair loss.
In the treatment of androgenetic alopecia (AGA), finasteride (FN) is the only oral medicine approved by Unites States Federal Drug Administation (US FDA) (1). FN is a specific type II $5 \alpha$-reductase enzyme inhibitor which reduces the conversion of androgen, testosterone (T) to dihydrotestosterone (DHT), the major inducer of AGA (1). Oral administration of $1 \mathrm{mg}$ daily can reduce the concentration of scalp and serum DHT approximately $64 \%$ and $68 \%$, respectively, inhibiting hair follicle miniaturization (2). Topical or transdermal delivery formulations of FN should be preferable in the future management of AGA with lower side effect than the oral formulation (3).

The dermal papilla cells (DPCs) have been recognized as cells secreting signaling molecules that control hair follicle and it is hypothesized that these cells are key targets of androgen in AGA pathophysiology (4-5). Hair regrowth cycle begins when the signals from DPCs reach the multipotent epidermal stem cells in the bulge region of hair follicle (6). The function and ability of DPCs to induce the regrowth of hair as well as maintain hair at the growing phase have been shown to depend on the stem cell properties of DPCs (7). Sox-2 is one of the stem cell-related transcription factors found in DPCs and functions in pluripotency maintenance. The important role of Sox-2 in hair growth has been demonstrated in transgenic animals and lack of this transcription factor that present an impairment of hair shaft outgrowth $(8,9)$. Besides, the presence of human stem cell protein markers such as CD133 suggests that DPCs have hair inductive properties (9). The activation of $\mathrm{Wnt} / \beta$-catenin signaling, especially $\mathrm{Wnt} 10 \mathrm{~b}$ is essential for hair development, hair cycling and hair regrowth (10). Also, this signal has been shown to regulate DPCs inductive properties (11). Wnt/ $\beta$-catenin has been shown to be the early trigger of DPCs in the induction and initiation of hair 
follicle formation (12). Together, active agents that induce or enhance stem cell signals and properties of DPCs may benefit the therapeutic treatment of hair loss. In this study, we evaluated the possible effects of $\mathrm{FN}$ on stemness maintenance of DPCs. The knowledge gained from this study may benefit the development of novel strategies to control hair loss.

\section{Materials and Methods}

Cells and reagents. Immortalized dermal papilla cells (DPCs) and Human dermal papilla primary cells culture 1 (HDPCs1) were obtained from Applied Biological Materials Inc. (Richmond, BC, Canada). Human dermal papilla primary cells culture 2 (HDPCs2) was purchased from Celprogen (Celprogen Inc., CA, USA). DPCs, HDPCs1 and HDPCs2 were cultured in Dulbecco's Modified Eagle's Medium (DMEM, Gibco Grand Island, NY, USA) containing 10\% fetal bovine serum (FBS) and 100 units $/ \mathrm{ml}$ of penicillin/streptomycin (Life technologies, $\mathrm{MD}, \mathrm{USA}$ ) at $37^{\circ} \mathrm{C}$ in a $5 \% \mathrm{CO}_{2}$ atmosphere. Finasteride (FN) and dimethylsulfoxide (DMSO) were purchased from Sigma (St. Louis, MO, USA). 3-(4,5-Dimethylthiazol-2-yl)-2,5-diphenyltetrazolium bromide (MTT) and Alexa Fluor 488/594 conjugated secondary antibody were from Invitrogen (Carlsbad, CA, USA). Rabbit monoclonal antibodies for integrin- $\beta 1, \beta$-catenin, phosphorylated ATPdependent tyrosine kinase (AKT, Ser 473), Nanog, Sox-2, CD44, $\beta$ actin, and HRP-conjugated secondary antibodies were obtained from Cell Signaling (Denver, MA, USA). Immobilon Western Chemiluminescent HRP substrate was from Thermo Fisher Scientific Inc. (Rockford, IL, USA). Hoechst 33342 and propidium iodide (PI) were obtained from Molecular Probes Inc. (Eugene, OR, USA).

Cell viability assay. The cytotoxicity of FN in DPCs and HDPCs was determined by MTT assay modified from Kiratipaiboon, 2015 (13). Briefly, $1 \times 10^{4}$ cells/well of DPCs and HDPCs were seeded in 96 well plates and incubated overnight. Cells were treated with different concentrations of FN (0.01-100 $\mu \mathrm{M})$ for $24 \mathrm{~h}$. After indicated treatments, cells were incubated with MTT for $3 \mathrm{~h}$ at $37^{\circ} \mathrm{C}$. The intensity of MTT product was measured at $570 \mathrm{~nm}$ using a microplate reader. Cell viability was calculated as percentage relative to non-treated (control) value using the formula

$$
\text { Cell viability }(\%)=\frac{\mathrm{A} 570 \text { of treatment }}{\mathrm{A} 570 \text { of control }} \times 100
$$

Nuclear staining assay

Apoptotic and necrotic cell death were detected by Hoechst 33342 and PI co-staining. Cells $(1 \times 104$ cells/well $)$ were seeded in a 96well plate and incubated overnight. Then, cells were treated with various concentrations of $\mathrm{FN}$ for $24 \mathrm{~h}$. After treatments, cells were stained with $10 \mu \mathrm{g} / \mathrm{ml}$ of Hoechst 33342 and $5 \mu \mathrm{g} / \mathrm{ml}$ of PI for 30 min at $37^{\circ} \mathrm{C}$ and visualized by a fluorescence microscope (Olympus IX 51 with DP70; Olympus America Inc., Centervalley, PA, USA).

Aggregation behavior evaluation of DPCs. DPCs were seeded at a density of $3 \times 10^{5}$ cells/dish onto $6 \mathrm{~cm}$ dishes and incubated overnight for cell attachment. Cells were cultured in the presence or absence of FN (10-100 $\mu \mathrm{M})$. Aggregation behavior of DPCs was observed at 5 days by a phase-contrast microscope (Olympus IX 51 with DP70; Olympus America Inc., Centervalley, PA, USA).
Scanning electron microscope (SEM). DPCs treated with various concentration of $\mathrm{FN}(100 \mu \mathrm{M})$ were fixed in $2.5 \%$ glutaraldehyde in phosphate buffer $\mathrm{pH} 7.2$ for $2 \mathrm{~h}$. Cells were washed two times with phosphate buffer and once with distilled water. DPCs were dehydrated with $30 \%, 50 \%, 70 \%, 95 \%$ and $100 \%$ ethanol for 5 min/each, dried, mount and coat with gold (sputter caoter, Balzers model SCD 040, Germany). Coated cells were observed under SEM (JEOL, model JSM6400, Japan).

Western blot analysis. Cells were seeded at a density of $3 \times 10^{5}$ cells/dish onto $6 \mathrm{~cm}$ dishes overnight and cultured with various concentrations of $\mathrm{FN}$ for $24 \mathrm{~h}$. Afterwards, cells were incubated in lysis buffer containing $20 \mathrm{mM}$ Tris- $\mathrm{HCl}(\mathrm{pH} 7.5), 0.5 \%$ Triton $\mathrm{X}$, $150 \mathrm{mM}$ sodium chloride, $10 \%$ glycerol, $1 \mathrm{mM}$ sodium orthovanadate, $50 \mathrm{mM}$ sodium fluoride, $100 \mathrm{mM}$ phenylmethylsulfonyl fluoride and commercial protease inhibitor cocktail (Roche Molecular Biochemicals) for $30 \mathrm{~min}$ on ice. Cell lysates were then collected and determined for protein concentration using the Bradford method (Bio-Rad, Hercules, CA, USA). Equal amount of protein of each sample $(70 \mu \mathrm{g})$ was heated in Laemmli loading buffer at $95^{\circ} \mathrm{C}$ for $5 \mathrm{~min}$ and subsequently loaded on $10 \%$ SDSpolyacrylamide electrophoresis. After separation, proteins were transferred onto $0.45 \mu \mathrm{m}$ nitrocellulose membranes (Bio-Rad). Subsequently, the membranes were blocked with $5 \%$ non-fat milk in TBST [ $25 \mathrm{mM}$ Tris $\mathrm{HCl}$ (pH7.5), $125 \mathrm{mM} \mathrm{NaCl}, 0.05 \%$ Tween20] at $4^{\circ} \mathrm{C}$ overnight, and then were incubated with specific primary antibodies at $4^{\circ} \mathrm{C}$ overnight. Membranes were washed 3 times with TBST for $5 \mathrm{~min}$ and incubated with horseradish peroxidase coupled secondary antibodies for $2 \mathrm{~h}$ at room temperature. The immune complexes were detected with chemiluminescence substrate (Supersignal West Pico; Pierce, Rockford, IL, USA) and quantified using Image $\mathbf{J}$ software (NIH, Bethesda, MD, USA).

Immunocytochemistry. Cells were seeded at a density of $1 \times 10^{4}$ cells/well in 96-well plates and incubated overnight. Cells were cultured with various concentration of FN (10-100 $\mu \mathrm{M})$ for 24 and $48 \mathrm{~h}$. Cells were fixed with $4 \%$ paraformaldehyde for $15 \mathrm{~min}$ and permeabilized with $0.5 \%$ Triton-X for $5 \mathrm{~min}$ at room temperature. After that, cells were incubated with $10 \%$ FBS and $0.1 \%$ Triton-X (blocking solution) for $1 \mathrm{~h}$ at room temperature. Cells were washed and incubated with specific primary antibodies ( $\beta$-catenin, Nanog, and Sox-2) at $4^{\circ} \mathrm{C}$ overnight. Secondary antibodies at dilution 1:100 were added following washing of cells with $10 \%$ FBS and $0.1 \%$ Triton-X. Hoechst 33342 in blocking solution at 1:1,000 dilution was added and incubated for $1 \mathrm{~h}$ at room temperature. Cells were fixed again with $4 \%$ paraformaldehyde for $10 \mathrm{~min}$ and were mounted with 50\% glycerol. Samples were examined with fluorescence microscope (Olympus IX 51 with DP70; Olympus America Inc., Centervalley, PA, USA).

Statistically analysis. Each experiment was repeated at least three times, and the data were expressed as mean \pm S.D. Statistical analysis was performed using one-way analysis of variance (ANOVA) and Tukey HSD test. $p$-Values less than 0.05 were considered as statistically significant.

\section{Results}

Effect of FN on viability of DPCs. Cells were treated with various concentrations of $\mathrm{FN}(0.01-100 \mu \mathrm{M})$ for $24 \mathrm{~h}$. Cell 

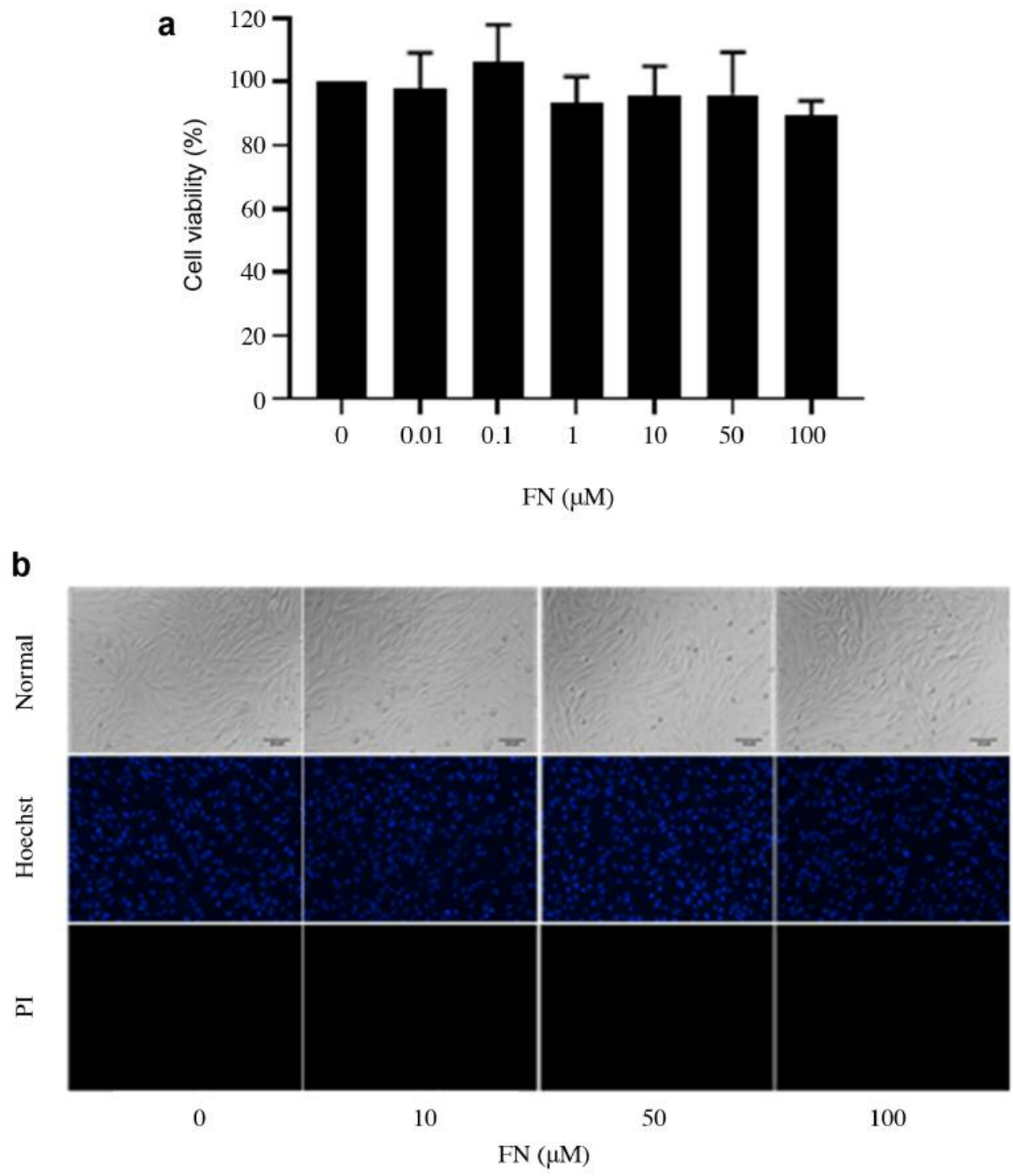

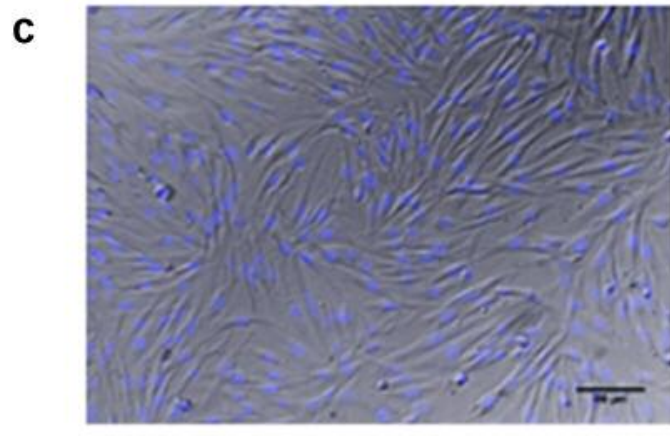

0

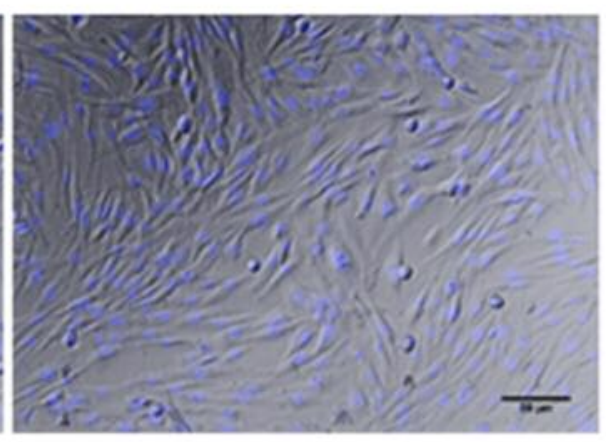

100

$\mathrm{FN}(\mu \mathrm{M})$

Figure 1. Cytotoxicity of FN on DPCs. (a) DPCs were treated with FN (0.01-100 $\mu M)$ for 24 h and cytotoxicity was determined by MTT assay. The data represent the means of three independent samples $\pm S D$. (b) Hoechst 33342/PI co-staining assay for investigating the mode of cell death after treatment for 24 h. (c) Morphology of DPCs. 
a

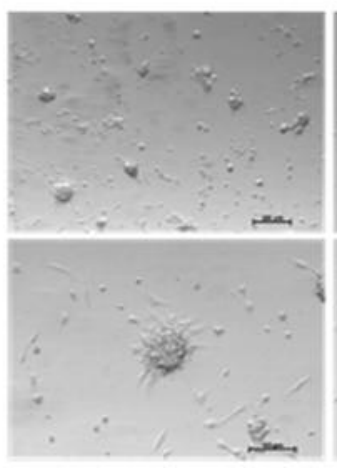

0

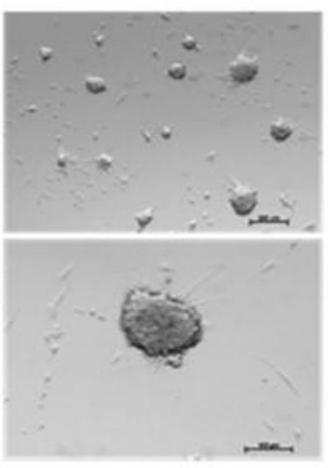

10
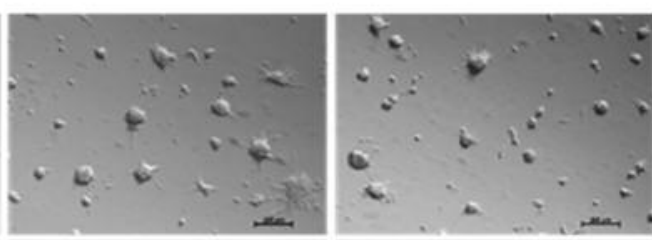

$4 X$

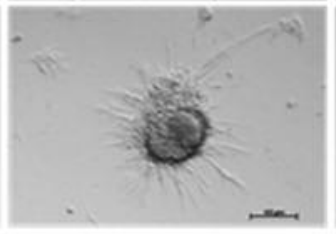

50

$\mathrm{FN}(\mu \mathrm{M})$

b

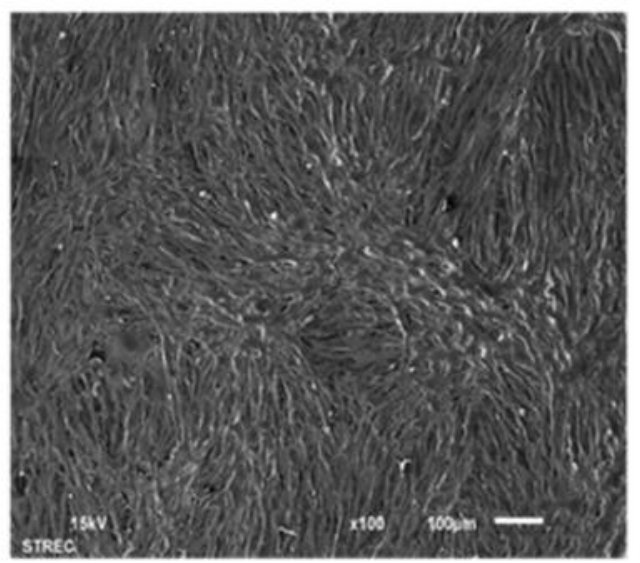

0

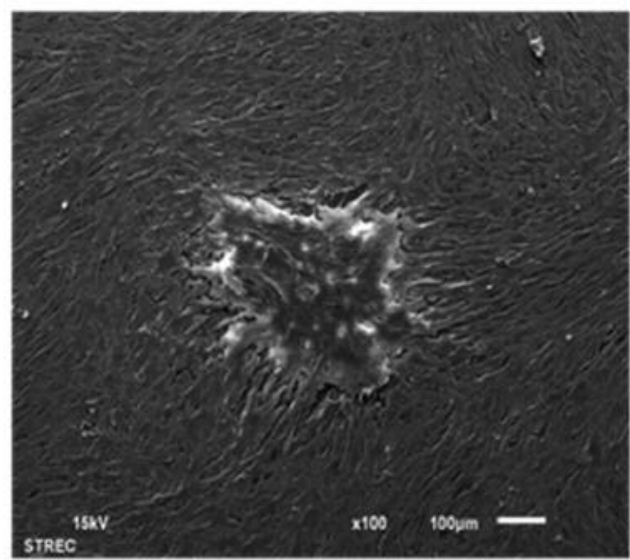

100

$\mathrm{FN}(\mu \mathrm{M})$

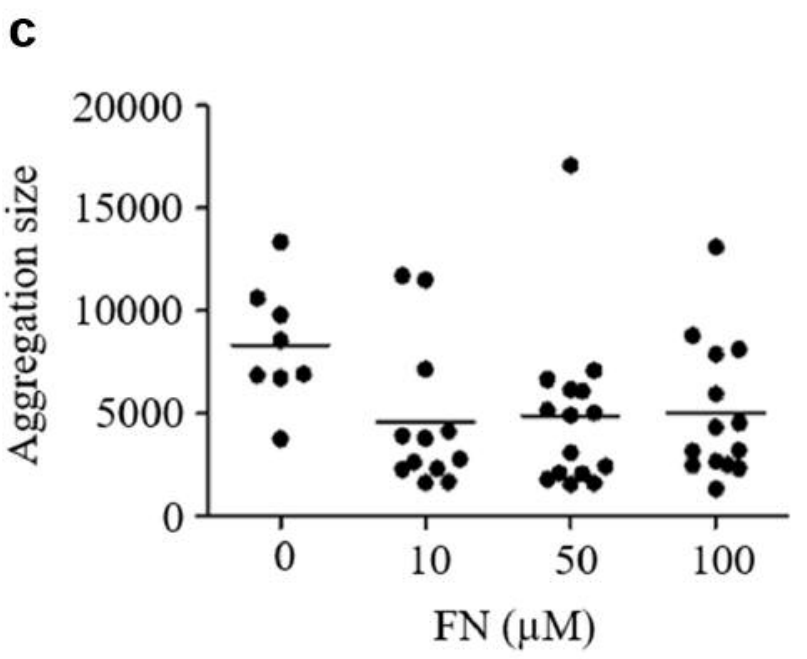

d

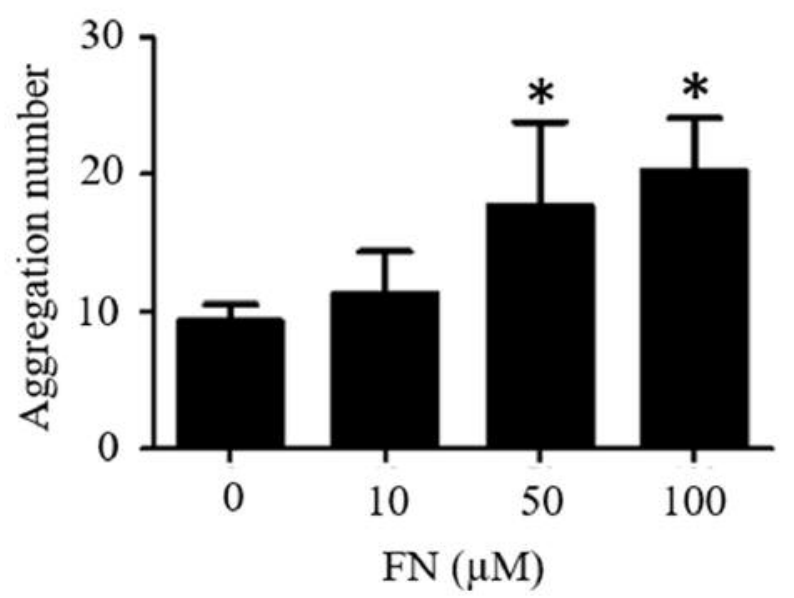

Figure 2. Aggregation behavior of DPCs. (a) Aggregation behavior of DPCs after treatment with FN (10-100 $\mu M$ ) for five days. (b) SEM image of the aggregation behavior of DPCs after treatment with $F N(100 \mu M)$ for five days. (c-d) Aggregation size and aggregation number were determined by image analyzer. The data represent the mean of three independent samples $\pm S D$. ${ }^{*} p<0.05$ versus non-treated control. 
a

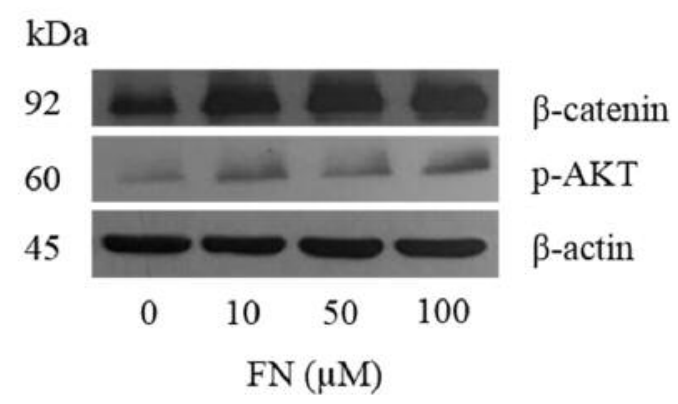

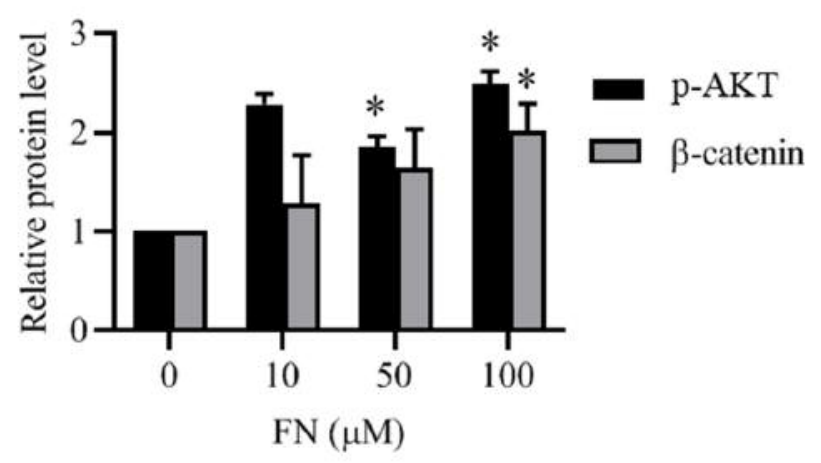

b $\beta$-catenin

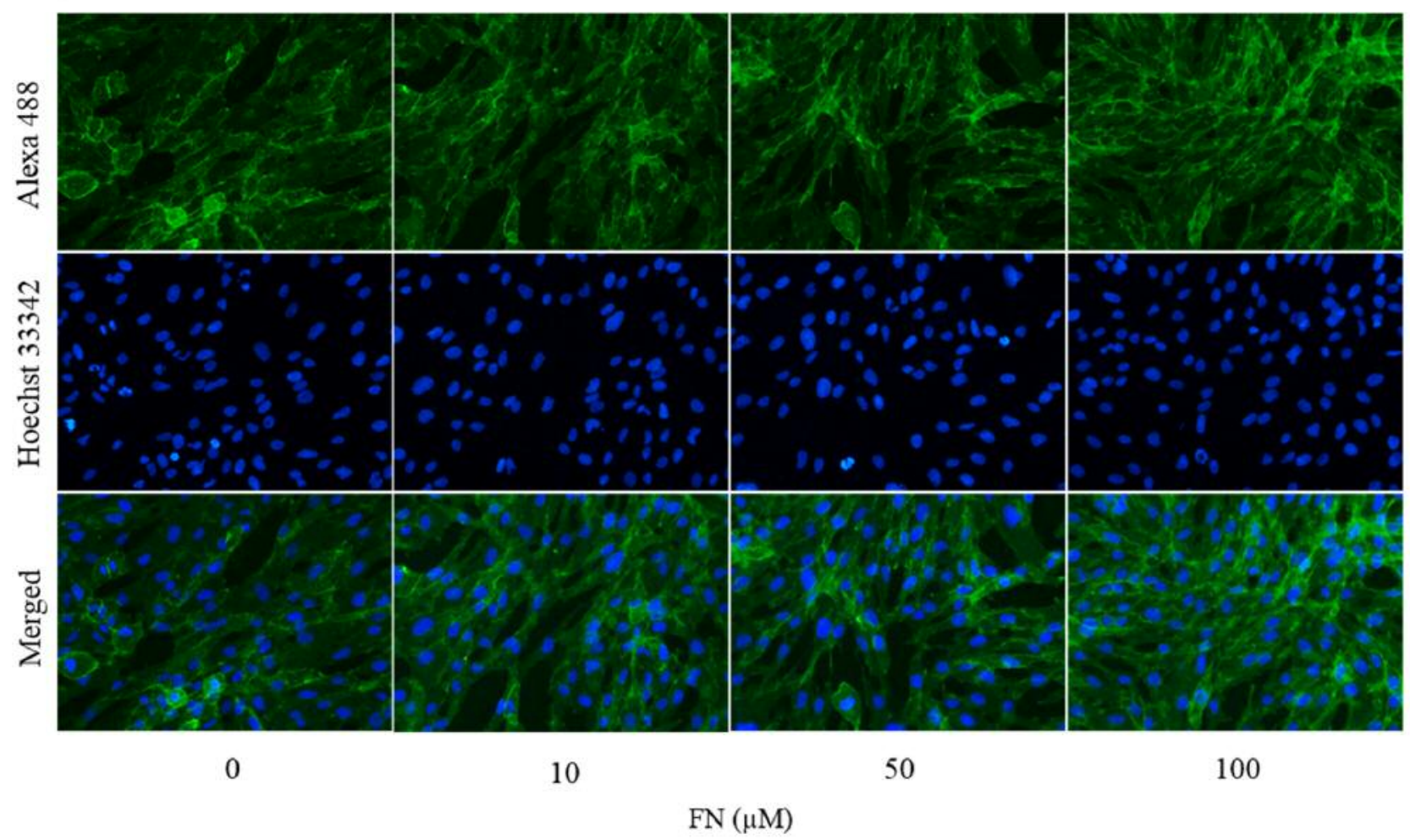

Figure 3. Effect of FN on Wnt/ $\beta$-catenin signaling in DPCs. Cells were cultured with various concentration of FN (10-100 $\mu M)$ for 24 h. (a) After treatment, the levels of Wnt/ $\beta$-catenin signaling ( $p$-AKT (Ser473) and $\beta$-catenin) were analyzed by western blot. $\beta$-actin was served as loading control. The immunoblot signals were quantified by densitometry. The data represent the means of three independent samples $\pm S D$. ${ }^{*} p<0.05$ versus non-treated control. (b) Expression of $\beta$-catenin was analyzed by immunofluorescence staining.

viability and cell death were evaluated by MTT and Hoechst 33342 /propidium iodide (PI) co-staining assay. FN had no significant effect on cell viability at concentrations ranging from 0.01 to $100 \mu \mathrm{M}$ (Figure 1a). The Hoechst/ PI apoptosis assay (Figure $1 \mathrm{~b}$ and $\mathrm{c}$ ), indicated that FN treatment (0.01$100 \mu \mathrm{M})$ caused neither apoptosis nor necrotic cell death. Therefore, the non-toxic doses of FN (10-100 $\mu \mathrm{M})$ were selected and used for the following experiments.
$F N$ enhances the aggregation pattern in DPCs. DPCs have been known as multipotent stem cells having the ability to control hair growth $(8-9,14,15)$. Here, we explored the effect of FN on the stem cell-like aggregation behavior in DPCs. Cells were treated with FN $(10-100 \mu \mathrm{M})$ for 5 days and the aggregation pattern of the cell was determined at day 5 . The aggregation patterns of DPCs are shown in Figure 2a (by a phase-contrast microscope) and Figure $2 b$ (by SEM). While 

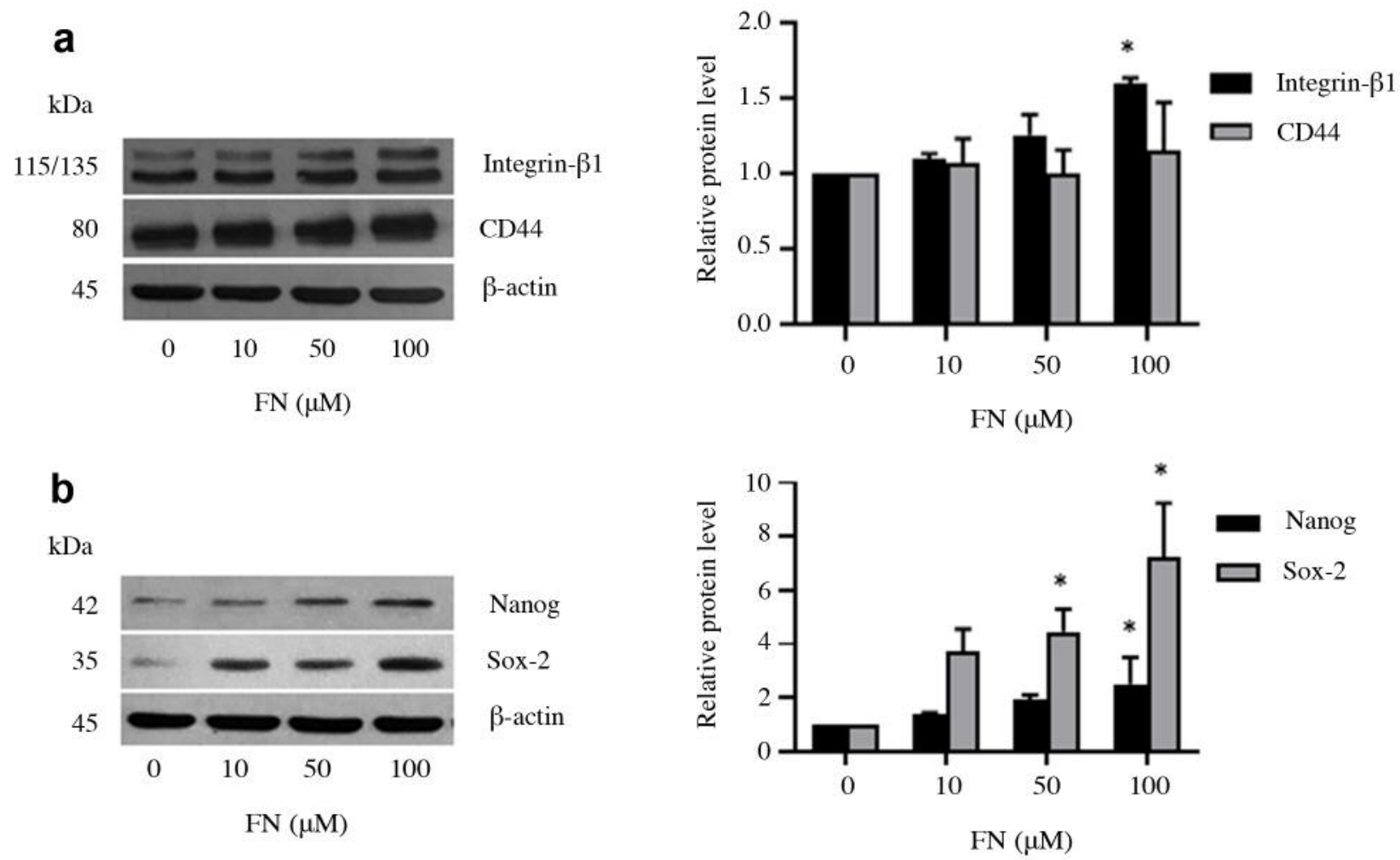

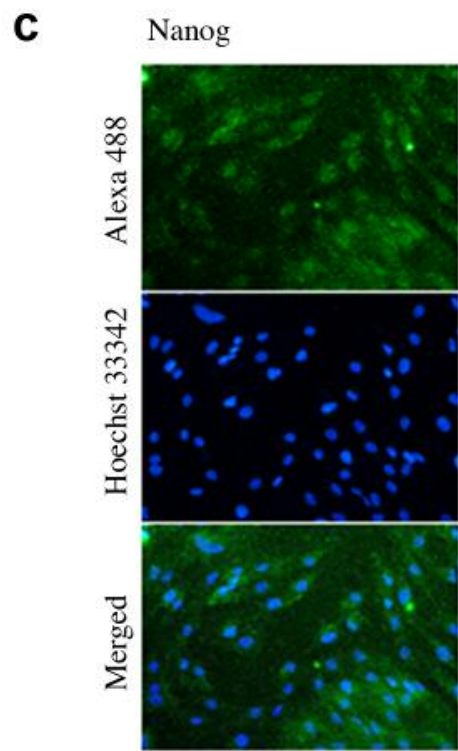

0

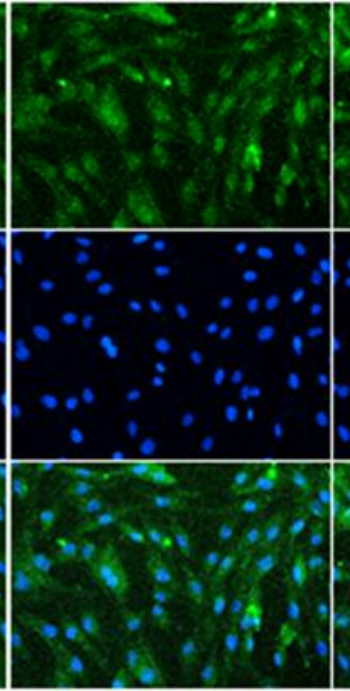

10

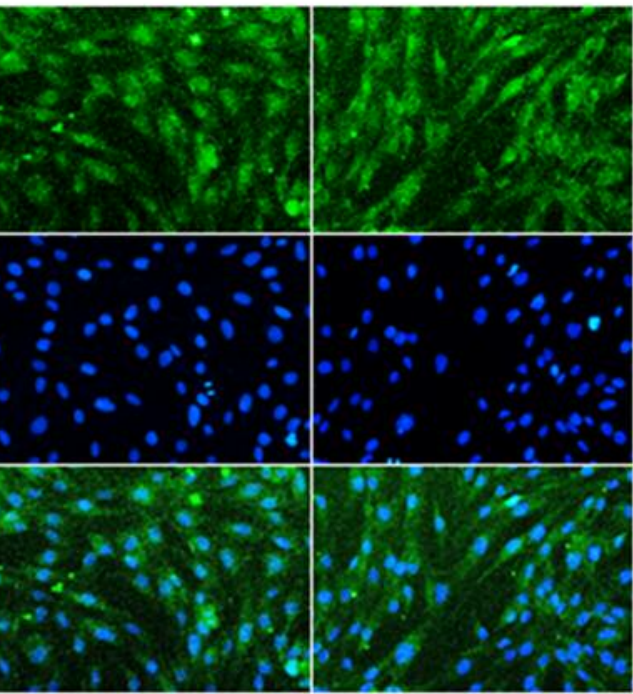

50

100

$\mathrm{FN}(\mu \mathrm{M})$

Figure 4. Continued

the size of aggregation was slightly decreased in response to FN treatment in comparison to control (Figure 2c), FN at the concentrations of 50 and $100 \mu \mathrm{M}$ significantly increased the number of aggregates of DPCs when compared with the control (Figure 2d).
Effect of FN on Wnt/ $\beta$-catenin signaling in DPCs. The $\mathrm{Wnt} / \beta$-catenin signaling plays an important role in maintaining stemness of stem cells involved in hair growth and hair regeneration (16). Activation of $\mathrm{Wnt} / \beta$-catenin leads to an increase in the stem cell compartment (17) and 


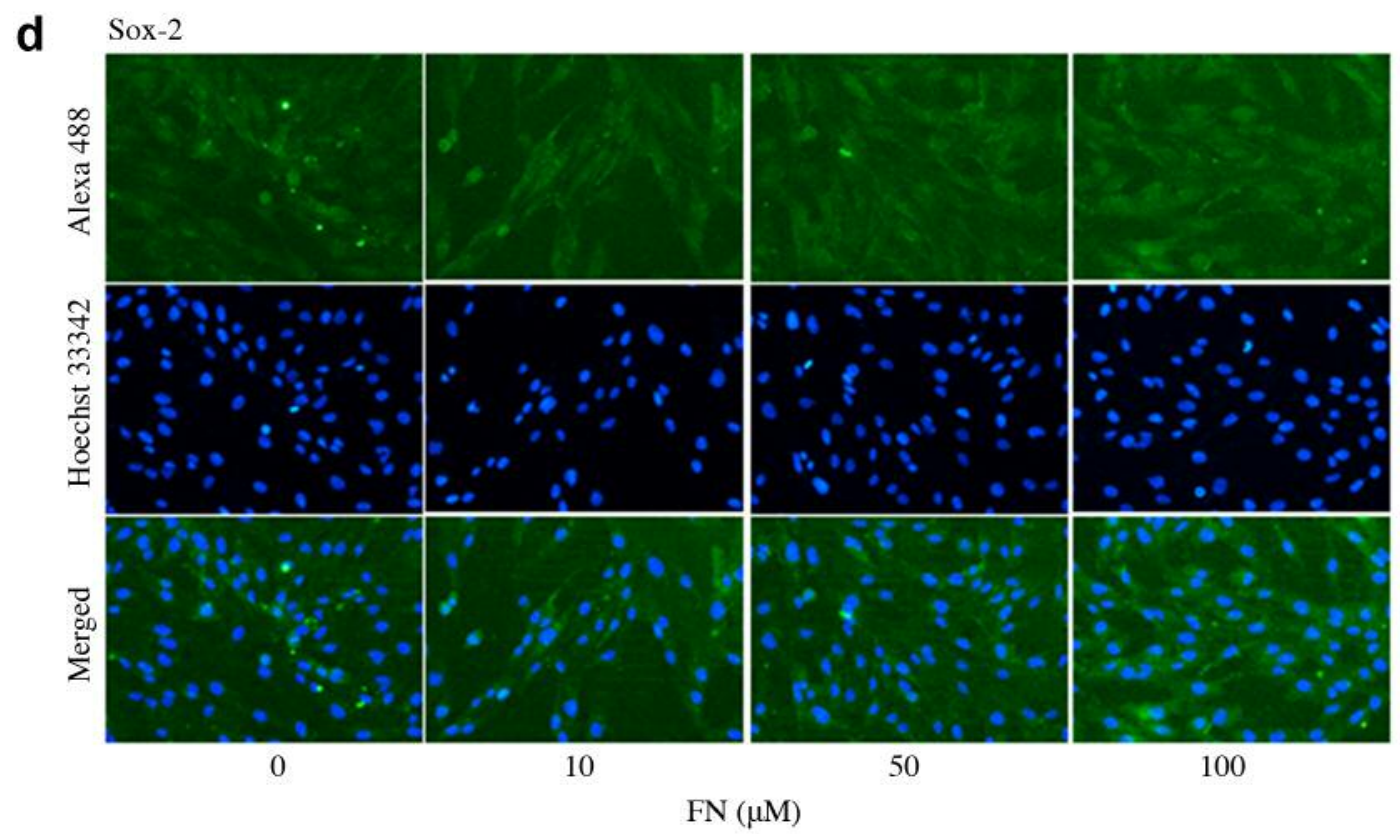

Figure 4. Effect of FN on stem cell-like phenotype and self-renewal transcription factors in DPCs. Cells were cultured with various concentrations of FN (10-100 $\mu \mathrm{M})$ for $24 \mathrm{~h}$. ( $a$ and b) After treatment, the levels of integrin $\beta 1, C D 44$, Nanog, Sox-2 were analyzed by western blot. $\beta$-actin was served as loading control. The immunoblot signals were quantified by densitometry. The data represent the means of three independent samples $\pm S D$. ${ }^{*} p<0.05$ versus non-treated control. ( $c$ and d) Expression of Nanog and Sox-2 was analyzed by immunofluorescence staining.

stimulation of DPCs to induce hair growth through the induction and initiation of hair follicle formation and prolongation of anagen phase. To determine whether FN affects $\mathrm{Wnt} / \beta$-catenin pathway in DPCs, the signaling proteins related to $\mathrm{Wnt} / \beta$-catenin including activated AKT (phosphorylated AKT (p-AKT) at Ser 473) and $\beta$-catenin were analyzed by western blot analysis. FN significantly increased the levels of p-AKT at the concentrations of 10$100 \mu \mathrm{M}$ (Figure 3a). In addition, $100 \mu \mathrm{M}$ FN significantly increased the expression levels of $\beta$-catenin. The induction of cellular $\beta$-catenin levels was confirmed by immunocytochemistry. Immunocytochemistry using the $\beta$ catenin antibody showed that FN-treated cells had augmented levels of $\beta$-catenin compared with the non-treated control (Figure 3b).

Effect of FN on stem cell markers and transcription factors. We further confirmed that FN treatment could increase stemness of DPCs by determining its effect on stem cell markers. The cells were cultured for $24 \mathrm{~h}$ in the presence or absence of non-toxic concentrations of FN. Then, the protein markers were analyzed by western blot analysis. Figure $4 \mathrm{a}$ shows that $100 \mu \mathrm{M} \mathrm{FN}$ increased the protein levels of integrin- $\beta 1$ in a dose-dependent manner, however, FN had only a slight effect on the levels of CD44.
Self-renewal transcription factors like Nanog and Sox-2 have been shown to play a major role in stem cell properties (18). We, therefore, investigated whether treatment of the DPCs with FN could increase the cellular levels of Nanog and Sox-2. Western blot results showed that FN increased the protein levels of Nanog and Sox-2 in a dose-dependent manner (Figure 4b). The induction of Nanog and Sox-2 was confirmed by immunocytochemistry. As shown in Figure 4c and d, FN increased the expression of Nanog and Sox-2 when compared with the non-treated control.

FN maintains the stem cell phenotypes in HDPCs. To confirm the stem cell induction property of FN in other DPCs, the human primary dermal papilla cells from two different donors were used. Primary DPCs were treated with various concentrations of FN (0.01-100 $\mu \mathrm{M})$ for $24 \mathrm{~h}$. FN at $100 \mu \mathrm{M}$ slightly decreased cell viability of HDPCs1 (Figure 5a). Meanwhile, FN (0.01-100 $\mu \mathrm{M})$ had no effect on cell viability of HDPCs2 (Figure 5b). Next, the characteristics of stem cells in these primary cells after treatment with FN (10-100 $\mu \mathrm{M})$ were examined. The expression of stem cell proteins was determined by immunocytochemistry. Consistently, the expression of $\beta$-catenin, Nanog, and Sox- 2 was increased in response to $\mathrm{FN}$ treatment in a dose-dependent manner in HDPCs1 and HDPCs2 (Figure 5c-h). 

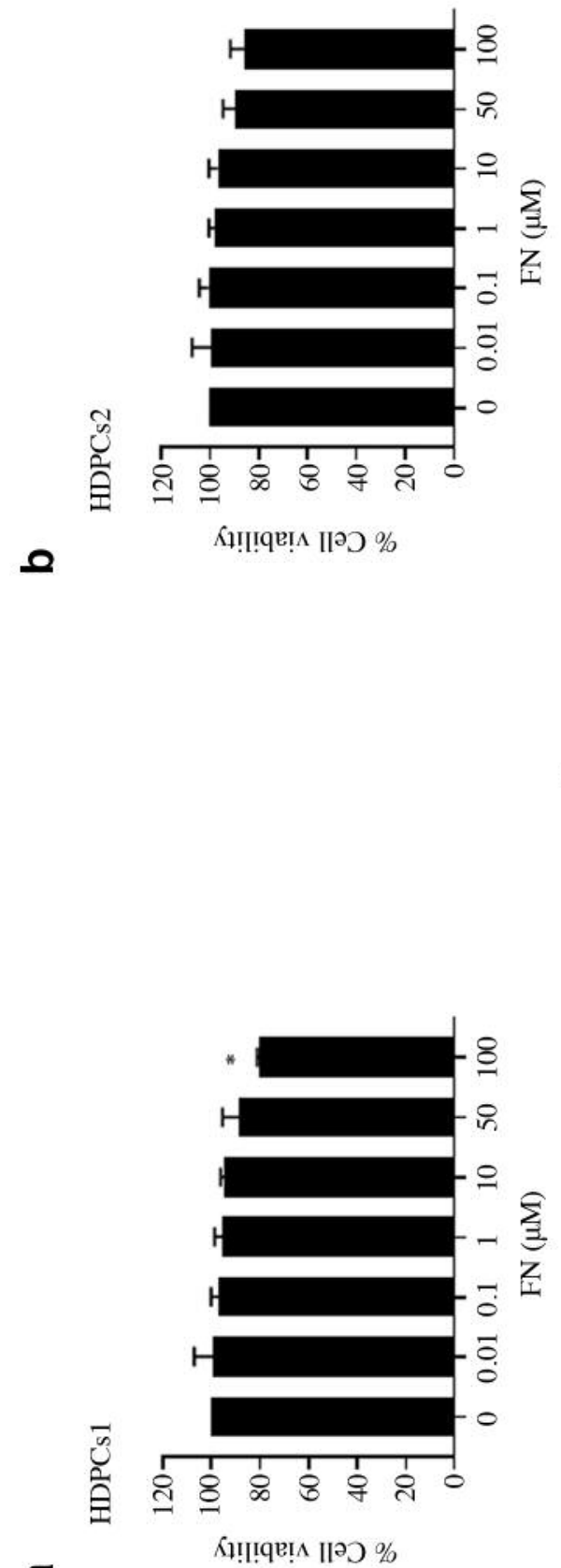

(

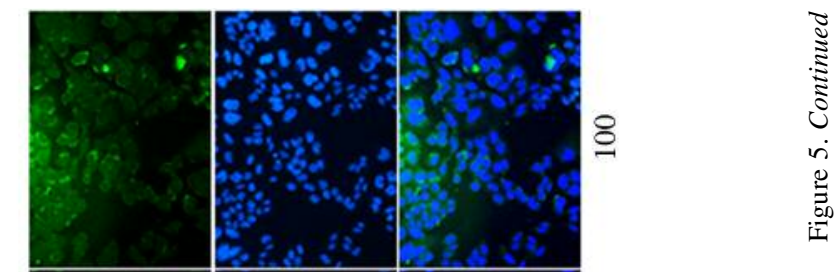

0
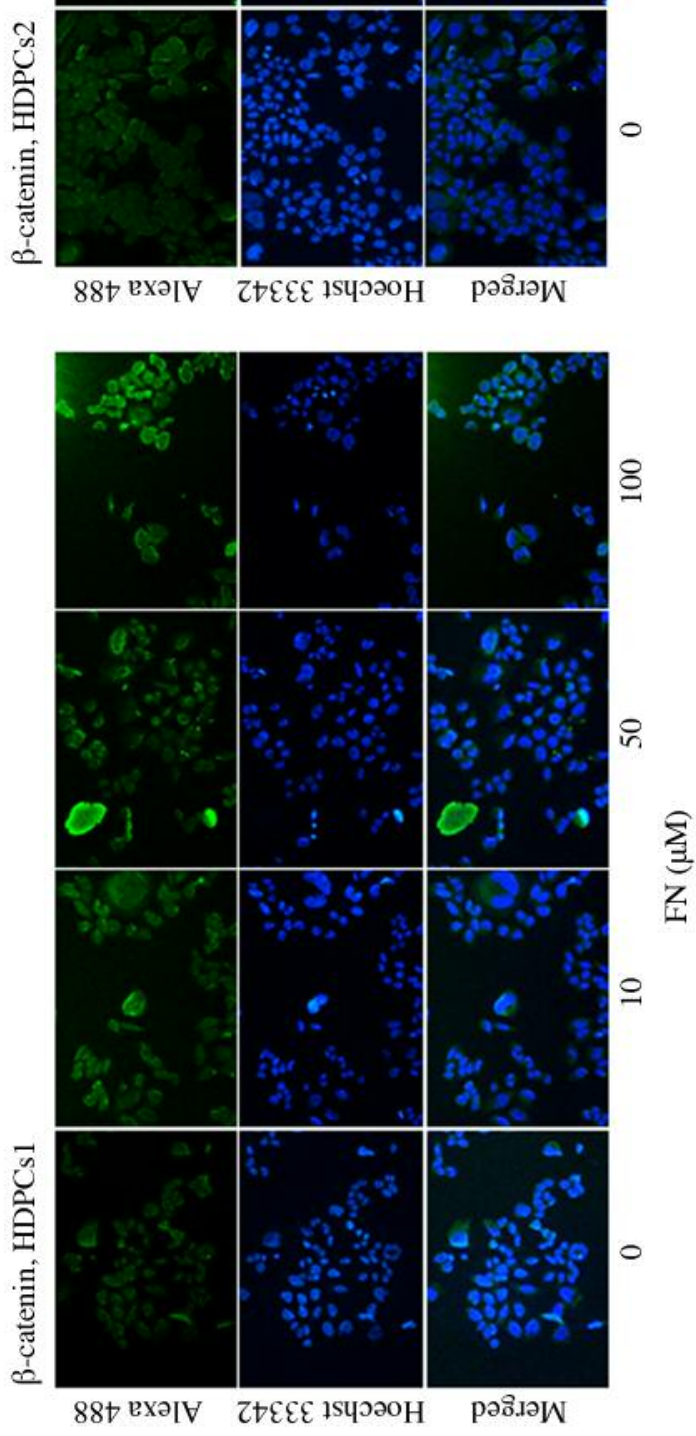


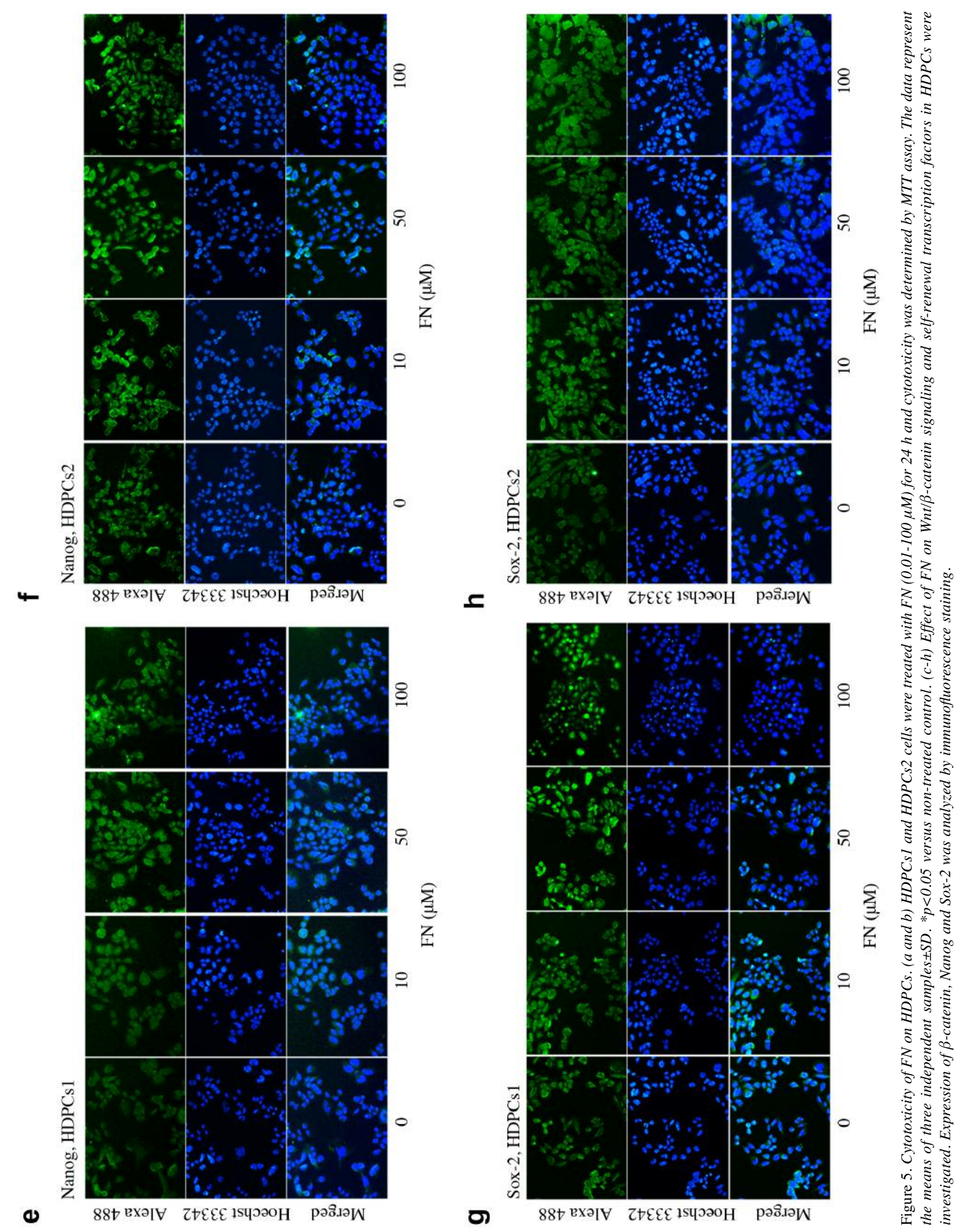




\section{Discussion}

Stem cell properties of DPCs play an important role in hair growth cycle and hair follicle formation (19). Thus, the augmentation of stemness in DPCs may increase the rate of hair growth and benefit hair loss control. Here, we report for the first time that FN, a widely prescribed drug for the treatment of hair loss, has a potentiating effect on the stem cell properties of DPCs.

The hair follicle formation by DPCs is related to their stem cell behaviors including aggregate behavior (20). Treatment of DPCs with non-toxic concentrations of FN significantly increased the number of cell aggregates in comparison to the non-treated control cells (Figure 2). Also, FN augmented the stem cell signals in DPCs by increasing the levels of stem cell markers and transcription factors (Figures 3 and 4 ). Wnt/ $\beta$ catenin is known to regulate stem cell characteristics and functions $(16,21)$. Inactivation of $\beta$-catenin in DPCs has been shown to cause hair growth reduction and impaired hair regeneration (22). In contrast, the activation of $\beta$-catenin signaling resulted in expansion and formation of hair follicles (23). $\beta$-catenin signaling is known to be controlled by several cellular mechanisms and the AKT signaling has been recognized as a key regulator of $\beta$-catenin. The activated AKT protein increases cellular levels of $\beta$-catenin by inhibiting GSK3 $\beta$-mediated ubiquitination and proteasomal degradation of $\beta$-catenin protein (24). We found that in response to $\mathrm{FN}$ treatment, activated AKT was increased together with the increase in cellular $\beta$-catenin (Figure 3a), suggesting that FN could maintain stem cell signaling through AKT/ $\beta$-catenindependent mechanism. Likewise, integrin- $\beta 1$ has been shown to play a role in hair follicle formation and stem cell maintenance (25-26). Hair follicle bulge stem cells have been shown to have high integrin- $\beta 1$ expression (27). We also found that treatment of the DPCs with FN induced high expression of integrin- $\beta 1$ (Figure $4 \mathrm{a}$ ).

The transcription factors that are important for selfrenewal properties of stem cells, namely, Sox-2 and Nanog have been widely used as biomarkers for human stem cell detection (28). Sox-2 plays an important role in maintaining pluripotency of stem cells (29). Sox-2 interacts and cooperates with other transcription factors, such as Nanog and Oct-4, for regulating stem cell pluripotency (28). Sox-2, Nanog, and Oct-4 form a core protein for allowing pluripotent stem cells to maintain their self-renewal. It has been shown that DPCs and hair follicle stem cells contain high level of Sox-2 (30), and this transcription factor regulates hair growth (8). The Sox-2 and Nanog were significantly upregulated in FN-treated DPCs, supporting our conclusion that FN may potentiate stemness and stem cell function of DPCs. Besides, the key evidence that FN accentuates stem cell signal was confirmed in human primary dermal papilla cells from 2 different sources.
Finasteride
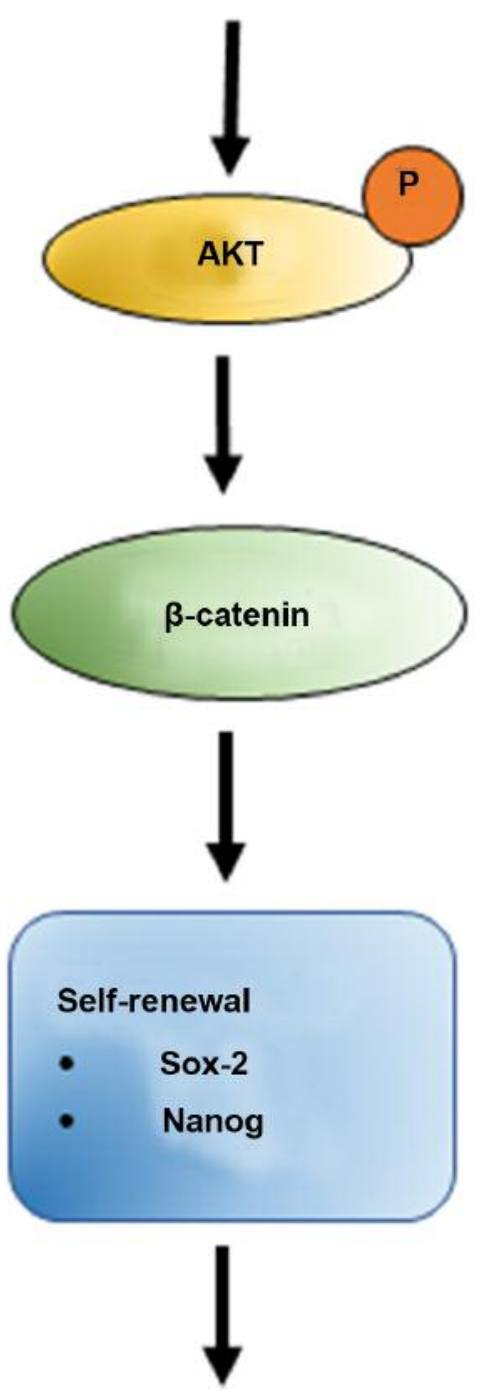

Stem cell maintenance

Figure 6. Schematic diagram summarizing the effects of $F N$ on the stemness in human DPCs. FN improves the stemness of human DPCs through AKT activation, which increases cellular levels of $\beta$-catenin. As a consequence, $\beta$-catenin accumulates in the cells resulting in an increasing of transcription of target genes including those involved in self-renewal.

\section{Conclusion}

This study unraveled a novel regulatory activity and mechanism by which FN regulates stem cell signals in DPCs. FN increases the stemness of the cells through AKT-dependent $\mathrm{Wnt} / \beta$-catenin signaling, resulting in the induction of transcription factors such as Sox-2 and Nanog (Figure 6). This study warrants further investigations to develop this approved drug for therapeutic and cosmeceutical applications. 


\section{Conflicts of Interest}

The Authors declare no potential conflicts of interest regarding this study.

\section{Authors' Contributions}

Conceptualization, T.N. and P.C.; Methodology, P.O., T.N. and P.C. Investigation, N.R., T.P., and P.C. Writing - original draft preparation, N.R., P.O., and T.N.; Writing - review and editing, P.C.; Funding acquisition, T.N. and P.C.; Supervision, P.O., T.N., and P.C. All Authors read and approved the final manuscript.

\section{Acknowledgements}

This work was supported by the grant for International Research Integration: Chula Research Scholar, Ratchadaphiseksomphot Endowment Fund and Silpakorn University Research and Development Institute (Grant No. SURDI 60/01/07).

\section{References}

1 Anitha B, Inamadar AC and Ragunatha S: Finasteride-its impact on sexual function and prostate cancer. J Cutan Aesthet Surg 2(1): 12-16, 2009. PMID: 20300365. DOI: 10.4103/09742077.53093

2 Singh MK and Avram M: Persistent sexual dysfunction and depression in finasteride users for male pattern hair loss: A serious concern or red herring? J Clin Aesthet Dermatol 7(12): 51-55, 2014. PMID: 25584139.

3 Valente Duarte de Sousa IC and Tosti A: New investigational drugs for androgenetic alopecia. Expert Opin Investig Drugs 22(5): 573589, 2013. PMID: 23550739. DOI:10.1517/ 13543784.2013.784743

4 Randall VA, Thornton MJ, Hamada K and Messenger AG: Mechanism of androgen action in cultured dermal papilla cells derived from human hair follicles with varying responses to androgens in vivo. J Invest Dermatol 98(6 Suppl): 86S-91S, 1992. PMID: 1588130.

5 Lai JJ, Chang P, Lai KP, Chen L and Chang C: The role of androgen and androgen receptor in skin-related disorders. Arch Dermatol Res 304(7): 499-510, 2012. PMID: 22829074. DOI: 10.1007/s00403-012-1265-X

6 Leiros GJ, Attorresi AI and Balana ME: Hair follicle stem cell differentiation is inhibited through cross-talk between Wnt/ $\beta$ catenin and androgen signalling in dermal papilla cells from patients with androgenetic alopecia. Br J Dermatol 166(5): 10351042, 2012. PMID: 22283397. DOI: 10.1111/j.1365-2133. 2012.10856.x

7 Yang CC and Cotsarelis G: Review of hair follicle dermal cells. J Dermatol Sci 57(1): 2-11, 2010. PMID: 20022473. DOI: 10.10 16/j.jdermsci.2009.11.005

8 Clavel C, Grisanti L, Zemla R, Rezza A, Barros R, Sennett R, Mazloom AR, Chung CY, Cai X, Cai CL, Pevny L, Nicolis S, Ma'ayan A and Rendl M: Sox2 in the dermal papilla niche controls hair growth by fine-tuning BMP signaling in differentiating hair shaft progenitors. Dev Cell 23(5): 981-994, 2012. PMID: 23153495. DOI: 10.1016/j.devcel.2012.10.013

9 Driskell RR, Giangreco A, Jensen KB, Mulder KW and Watt FM: Sox2-positive dermal papilla cells specify hair follicle type in mammalian epidermis. Development 136(16): 2815-2823, 2009. PMID: 19605494. DOI: $10.1242 /$ dev.038620

10 Kishimoto J, Burgeson RE and Morgan BA: Wnt signaling maintains the hair-inducing activity of the dermal papilla. Genes Dev 14(10): 1181-1185, 2000. PMID: 10817753.

11 Shimizu $\mathrm{H}$ and Morgan BA: Wnt signaling through the betacatenin pathway is sufficient to maintain, but not restore, anagen-phase characteristics of dermal papilla cells. J Invest Dermatol 122(2): 239-245, 2004. PMID: 15009701. DOI: 10.1046/j.0022-202X.2004.22224.X

12 Lu GQ, Wu ZB, Chu XY, Bi ZG and Fan WX: An investigation of crosstalk between $\mathrm{Wnt} / \beta$-catenin and transforming growth factor- $\beta$ signaling in androgenetic alopecia. Medicine (Baltimore) 95(30): e4297, 2016. PMID: 27472703. DOI: 10.109 7/MD.0000000000004297

13 Kiratipaiboon C, Tengamnuay $\mathrm{P}$ and Chanvorachote P: Glycyrrhizic acid attenuates stem cell-like phenotypes of human dermal papilla cells. Phytomedicine 22(14): 1269-1278, 2015. PMID: 26626191. DOI: 10.1016/j.phymed.2015.11.002

14 Driskell RR, Juneja VR, Connelly JT, Kretzschmar K, Tan DW and Watt FM: Clonal growth of dermal papilla cells in hydrogels reveals intrinsic differences between Sox2-positive and -negative cells in vitro and in vivo. J Invest Dermatol 132(4): 1084-1093, 2012. PMID: 22189784. DOI: 10.1038/jid.2011.428

15 Ito Y, Hamazaki TS, Ohnuma K, Tamaki K, Asashima M and Okochi H: Isolation of murine hair-inducing cells using the cell surface marker prominin-1/CD133. J Invest Dermatol 127(5): 1052-1060, 2007. PMID: 17185982. DOI: 10.1038/sj.jid.5700 665

16 Merrill BJ: Wnt pathway regulation of embryonic stem cell selfrenewal. Cold Spring Harb Perspect Biol 4(9): a007971, 2012. PMID: 22952393. DOI: 10.1101/cshperspect.a007971

17 Kretzschmar K and Clevers H: Wnt/ $\beta$ catenin signaling in adult mammalian epithelial stem cells. Dev Biol 428(2): 273-282, 2017. PMID: 28526587. DOI: 10.1016/j.ydbio.2017.05.015

18 He S, Nakada D and Morrison SJ: Mechanisms of stem cell selfrenewal. Annu Rev Cell Dev Biol 25: 377-406, 2009. PMID: 19575646. DOI: 10.1146/annurev.cellbio.042308.113248

19 Armstrong L, Hughes O, Yung S, Hyslop L, Stewart R, Wappler I, Peters H, Walter T, Stojkovic P, Evans J, Stojkovic M and Lako M: The role of PI3K/AKT, MAPK/ERK and NFkappabeta signalling in the maintenance of human embryonic stem cell pluripotency and viability highlighted by transcriptional profiling and functional analysis. Hum Mol Genet 15(11): 1894-1913, 2006. PMID: 16644866 . DOI: $10.1093 / \mathrm{hmg} / \mathrm{ddl} 112$

20 Osada A, Iwabuchi T, Kishimoto J, Hamazaki TS and Okochi H: Long-term culture of mouse vibrissal dermal papilla cells and de novo hair follicle induction. Tissue Eng 13(5): 975-982, 2007. PMID: 17341162 . DOI: 10.1089/ten.2006.0304

21 Miki T, Yasuda SY and Kahn M: Wnt/ $\beta$-catenin signaling in embryonic stem cell self-renewal and somatic cell reprogramming. Stem Cell Rev 7(4): 836-846, 2011. PMID: 21603945. DOI: $10.1007 / \mathrm{s} 12015-011-9275-1$

22 Enshell-Seijffers D, Lindon C, Kashiwagi M and Morgan BA: beta-catenin activity in the dermal papilla regulates morphogenesis and regeneration of hair. Dev Cell 18(4): 633-642, 2010. PMID: 20412777. DOI: 10.1016/j.devcel.2010.01.016

23 Huelsken J, Vogel R, Erdmann B, Cotsarelis G and Birchmeier $\mathrm{W}$ : beta-catenin controls hair follicle morphogenesis and stem cell differentiation in the skin. Cell 105(4): 533-545, 2001. PMID: 11371349. 
24 Fukumoto S, Hsieh CM, Maemura K, Layne MD, Yet SF, Lee KH, Matsui T, Rosenzweig A, Taylor WG, Rubin JS, Perrella MA and Lee ME: AKT participation in the Wnt signaling pathway through dishevelled. J Biol Chem 276(20): 1747917483, 2001. PMID: 11278246. DOI: 10.1074/jbc.C000880200

25 Raghavan S, Bauer C, Mundschau G, Li Q and Fuchs E: Conditional ablation of beta1 integrin in skin. Severe defects in epidermal proliferation, basement membrane formation, and hair follicle invagination. J Cell Biol 150(5): 1149-1160, 2000. PMID: 10974002.

26 Conti FJ, Rudling RJ, Robson A and Hodivala-Dilke KM: alpha3beta1-integrin regulates hair follicle but not interfollicular morphogenesis in adult epidermis. J Cell Sci 116(Pt 13): 27372747, 2003. PMID: 12759370. DOI: 10.1242/jcs.00475

27 Akiyama M, Smith LT and Shimizu H: Changing patterns of localization of putative stem cells in developing human hair follicles. J Invest Dermatol 114(2): 321-327, 2000. PMID: 10651993. DOI: 10.1046/j.1523-1747.2000.00857.x
28 Boyer LA, Lee TI, Cole MF, Johnstone SE, Levine SS, Zucker JP, Guenther MG, Kumar RM, Murray HL, Jenner RG, Gifford DK, Melton DA, Jaenisch R and Young RA: Core transcriptional regulatory circuitry in human embryonic stem cells. Cell 122(6): 947-956, 2005. PMID: 16153702. DOI: 10.1016/j.cell.2005. 08.020

29 Arnold K, Sarkar A, Yram MA, Polo JM, Bronson R, Sengupta S, Seandel M, Geijsen N and Hochedlinger K: Sox2(+) adult stem and progenitor cells are important for tissue regeneration and survival of mice. Cell Stem Cell 9(4): 317-329, 2011. PMID: 21982232. DOI: 10.1016/j.stem.2011.09.001

30 Rendl M, Lewis L and Fuchs E: Molecular dissection of mesenchymal-epithelial interactions in the hair follicle. PLoS Biol 3(11): e331, 2005. PMID: 16162033. DOI: 10.1371/journal. pbio.0030331

Received April 29, 2019

Revised June 6, 2019

Accepted June 10, 2019 